\title{
Recent Development in International Treaties Relating to Aviation: New Standardization of International Air Law
}

\author{
Adi Kusumaningrum* \\ DOI: https://doi.org/10.22304/pjih.v7n2.a7
}

Submitted: June 15, 2020 | Accepted: August 31, 2020

\begin{abstract}
Globalization is identified with the development of treaties into national domain law. Initially, such treaties did not appear as legal regulations but as standard/harmonizedsetting for member states. Since the establishment of Chicago Convention on Civil Aviation, 1944, treaties on aviation keep developing well both on the aviation operational technique and economic aspect. Those treaties nowadays have turned into the source of international aviation law. Treaty has been one of the bases of domestic law for almost nations in the world. As a result, the global requirements need to be adjusted into national law of states. States are bound both legally and politically to verdicts of International organizations. The process of regulation and decision making in International organizations should be based on democratic procedures of member states either in the construction of final draft or in negotiation and arrangement of regulation or resolution drafts. Specifically, this article discusses recent development of international treaties relating to aviation from both operational and economic aspects. Following Assembly $39^{\text {th }}$ Session, ICAO, member states of ICAO, including Indonesia, made several multilateral agreements. The ratification of International treaties should consider the effects on legal, political, and security aspects. For Indonesia, one of the aspects that should never be neglected is strategic airspace, both geographically and geopolitically.
\end{abstract}

Keywords: aviation, international air law, new standardization.

\section{Perkembangan Terkini dalam Perjanjian Internasional Terkait Penerbangan: Standardisasi Baru Hukum Udara Internasional}

\begin{abstract}
Abstrak
Globalisasi ditandai dengan berkembangnya perjanjian-perjanjian internasional yang menjadi domain hukum nasional. Perjanjian-perjanjian semacam ini tidak langsung menciptakan aturan hukum, melainkan hanya melakukan standard/harmonized-setting yang kemudian akan diundangkan oleh negara-negara anggota dalam hukum nasionalnya. Pasca lahirnya Konvensi Chicago 1944, perjanjian internasional di bidang penerbangan terus berkembang baik aspek teknis operasional penerbangan maupun ekonomi. Perjanjianperjanjian internasional tersebut berkembang menjadi sumber hukum udara internasional. Traktat atau perjanjian internasional telah menjadi salah satu sumber hukum nasional

PADJADJARAN Journal of Law Volume 7 Number 2 Year 2020 [ISSN 2460-1543] [e-ISSN 2442-9325]

Lecturer of the Faculty of Law, Universitas Brawijaya, Jl. MT. Haryono 169 Malang, Dr. (Universitas Padjadjaran), S.H. (Universitas Brawijaya), M.H. (Universitas Brawijaya), adi.kusumaningrum@gmail.com
\end{abstract}


(domestik) bagi hampir seluruh negara-negara di dunia. Hal ini memberikan konsekuensi adanya penggabungan ketentuan-ketentuan internasional pada hukum nasional suatu negara. Negara terikat baik secara hukum maupun politik terhadap keputusan organisasi internasional di mana negara yang bersangkutan menjadi anggotanya. Aturan hukum dan proses pengambilan keputusan dari organisasi internasional sepenuhnya harus didasarkan pada prosedur yang demokratis bagi semua negara anggotanya baik dalam pengambilan keputusan final text maupun dalam negosiasi dan drafting suatu peraturan atau resolusi. Tulisan ini khusus membahas tentang perkembangan perjanjian internasional bidang penerbangan, baik aspek operasional maupun ekonomi. Sidang Majelis ICAO yang ke-39 merekomendasikan beberapa perjanjian multilateral yang didorong untuk dilaksanakan di negara-negara anggota ICAO, termasuk Indonesia. Ratifikasi penjanjian internasional di bidang penerbangan tersebut harus mempertimbangkan implikasinya baik secara hukum, politik dan keamanan. Dalam konteks Indonesia, landasan dasar penting dalam ratifikasi perjanjian-perjanjian internasional di bidang penerbangan adalah posisi strategis ruang udara Indonesia baik secara geografis maupun geopolitis.

Kata kunci: hukum udara internasional, penerbangan, standardisasi baru.

\section{A. Introduction}

Theorists have developed many ideas to identify position and interaction between international and domestic laws. There are two proponent theories among experts in Indonesia. First, the theory of dualism perceives international and domestic laws as separate systems of laws requiring international law to be ratified in national law. ${ }^{1}$ This view argues that international and domestic laws have respective objects of regulation since international law regulates interaction of states; while domestic law deals with the rights and responsibilities of citizens of state. ${ }^{2}$ Consequently, international law is unable to alter or terminate domestic law and vice versa. ${ }^{3}$ Second, the theory of monism views international and domestic laws as a single law system. Treaties are implemented in domestic law in accordance to international norms. ${ }^{4}$ According to this theory, there is no separation of implementation between international and domestic scopes since both are a single unified system. ${ }^{5}$ Once states bind in a treaty, they choose to incorporate the treaty

1 Damos Dumoli Agusman in Shinta Dewi (eds), Peran Hukum Dalam Pembangunan di Indonesia: Kenyataan, Harapan dan Tantangan, Bandung: Remaja Rosdakarya, 2013, p. 259.

2 Atip Latifulhayat, "Hubungan Hukum Internasional dalam Teori dan Praktik" in Susi Dwi Harjanti (eds), Negara Hukum yang Berkeadilan, Bandung: Pusat Studi Kebijakan Negara Fakultas Hukum Universitas Padjadjaran (PSKN FH UNPAD), 2011, p. 180. Furthermore, according to Tripel, one of the dualists, there are two main differences between domestic and international law: (1) The subjects of domestic law are individuals and the subject of international law are states; (2) The source of domestic law is the will of state and the source of international law is the common will of states.

3 Ibid.

4 Damos Dumoli Agusman, "Status Perjanjian Internasional Menurut Pandangan Mahkamah Konstitusi RI: Kajian Kritis terhadap Keputusan MK tentang Piagam ASEAN" in Shinta Dewi et al. (ed), loc. cit.

5 Law enforcer can directly use agreement norms in its forms as international norms. International and domestic laws essentially regulate same object, individual. However, international law commonly perceives as law that regulates relationship among states but originally it concerns about the relationship among individuals since states are no more than groups of individuals. 
into the domestic law (e.g. through ratification). Therefore, national legislation that implements the treaty is seen unnecessary. Even when a state has national legislation that regulates same issues, the legislation only acts as the implementation of the treaty. In this case, the international law in the domestic system stays in its character as International law. The theory of monism produces three concepts: (1) the primacy of municipal law, (2) the primacy of international law, and (3) monist naturalist. ${ }^{6}$

In the midst of the theoretical debate between monists and dualists, the concept of 'harmonization' occurs as an alternative for both. ${ }^{7}$ This view is against the superiority of international and domestic law. Each system of law is superior is its own territory. Many experts approve the concept as a pragmatic approach. States consider international law special system of law beyond domestic law. However, some aspects may be valid in domestic sphere. ${ }^{8}$

International Treaty is one of the main sources of International law as it is mentioned in Article 38 (Paragraph 1) of the Statute of the International Court of Justice as a "juridical basis" to make International Treaty as one of the sources of International law. However, this article does not imply that international law is higher than International custom. The evidence is that general practices are accepted as law or the general principles of law are recognized by civilized nations. The article states that all sources of International law have the same standing.

International treaty is a law instrument that accommodates the will and agreement of states or other subjects of International law to achieve common objectives according to International law. International treaty is also a basis of states' activity and other subjects of International law. The making of treaty is a legal action that binds all parties to involve in treaty.

Wallace states that treaty represents the most realistic and reliable identification method of states' agreement. ${ }^{9}$ It is because international treaties, in written form, provide better legal insurance for the involved and the third parties. For instance, content, intention, and objective of all parties, even the implicit ones, could be identified through reading and understanding the treaty's draft. That includes methods of making, legal binding, and length of validity. States of the world have regulated and acknowledged them formally. ${ }^{10}$

In a narrower scope, international treaty is defined as statement of agreement involving two or more subjects of International law (states, Holy See, liberation group, International organization, etc.) on a certain object that is formulated in

\footnotetext{
Atip Latifulhayat, in Susi Dwi Harjanti et al. (ed), op.cit., pp. 177-178.

Ibid., p. 181.

Ibid.

Rebecca M Wallace, Hukum Internasional, translated by Bambang Arumanadi, Semarang : IKIP Semarang Press, 1996, p. 21.

10 I Wayan Parthiana, Pengantar Hukum Internasional, Bandung: Mandar Maju, 1990, p. 159.
} 
written form and liable to International law. ${ }^{11}$ Article 2 (Paragraph 1) of Vienna Convention on the Law of Treaties (VCLT), 1969, defines treaty as follows.

"Treaty is agreement concluded between States in written form and governed by international law, whether embodied in a single instrument or in two or more related instruments and whatever its particular designation."

Therefore, according to the VCLT, treaty is an International agreement among states in written form and regulated by International law. It can be in the form of one single, two, or more instruments that are related one another whatever the particular designations are. Another definition of treaty is mentioned in Article 1 paragraph (1) of 1986 VCLT as follows.

"Treaty means an international agreement governed by international law and concluded in written form

(i) between one or more States and one or more international organizations; or

(ii) between international organization, whether that agreement is embodied in a single instrument or in two or more related instruments and whatever its particular designation."

Based on the definition, treaty is an international agreement that is liable to International law, formulated in written form, and involves one or more states and one or more international organization, or among international organizations. It could be in the form of one or more instruments that are related one another, whatever the particular designations are. In addition, English reckons many terms referring to treaty, such as convention, agreement, arrangement, declaration, charter, covenant, statute, protocol, pact, verbal process, modus vivendi, act, final act, and general act. ${ }^{12}$

The case of consent to be bound by treaty can be expressed through several means. It also depends on when the agreement is held. The consent to be bound by treaty may be represented by signature, ratification, statement of accession, or acceptance to an agreement. A state may bind themselves by signing a treaty without ratification when they want. Such intention could be written on a treaty or when members agree that the treaty will be in effect after the signature without waiting for ratification. Such treaty valid after signature without ratification can also be expressed by a statement that the treaty will be in effect after the signature, on the date of the announcement, or after the date of the establishment. ${ }^{13}$

\footnotetext{
I Wayan Parthiana, Perjanjian Internasional Bagian 1, Bandung: CV. Mandar Maju, 2002, pp. 13-15.

Ibid., p. 27.

13 Mochtar Kusumaatmadja and Etty R. Agoes, Pengantar Hukum Internasional, Bandung : Alumni, 2003, pp. 128129.
} 
A state can also be bound to a treaty by exchanging letters or draft when they wish so. This is done when the treaty is relatively simple. It consists of exchanging letters or exchanging notes. By exchanging signed letters, an agreement that binds both parties has been concluded. However, exchange of letters is a different form compared to an exchange of treaty ratification charter. ${ }^{14} \mathrm{~A}$ treaty, which has fulfilled requirement and stages to take effect, should be implemented by all parties as regulated in Article 2 (Paragraph 1, letter g) of the VCLT, 1969.

The development of international aviation law, according to Abeyratne, requires better attention than mere comments. ${ }^{15}$ Aviation law is a law that regulates the aeronautical use of airspace. It was originated since human encounter the art of air navigation. The practice later creates relations and social conflicts requiring legal regulation. ${ }^{16}$ Based on the history of land and sea territory, state sovereignty on airspace has been acknowledged. Nonetheless, the principle of air sovereignty above the territory is made as to the law principle as accepted internationally after the World War II.

After the establishment of the Chicago Convention 1944, treaties of aviation have been well developed both in the aspects of aviation operational technique and economical. The Chicago Convention 1944 regulated technical aspects of the operation of aviation. However, the Convention has failed to regulate economical and commercial issues. Two other treaties of Chicago Convention, the International Air Service Transit Agreement and the International Air Transport Agreement, did not result in much ratification. Therefore, rights of aviation covering states were made based on bilateral agreements. ${ }^{17}$

\section{B. Recent Development in International Treaties Relating to Aviation \\ 1. International Treaties Relating to Operational Aviation}

International Civil Aviation Organization (ICAO) is the competent body for the most comprehensive package of regulations on international civil aviation. As a civil aviation organization, ICAO has 'the rulemaking function' ability. ${ }^{18}$ Every legislation

\footnotetext{
14 Ibid., p. 129.

15 Ruwantissa Abeyratne, Essential Air and Space Law, Utrecht: Eleven International Publishing, 2008, p. 5.

16 Ibid.

17 Commonly, the bilateral agreement was conducted based on the agreement pattern by United States of America and United Kingdom that referred as Bermuda Agreement (1946). That Regime of Bilateralism surely is complicated since it requires many agreements between states.

18 Bin Cheng argues that the ICAO function, as legislative in aviation technique, is quasi-legis/ative since international standard does not bind states. They have to obey the regulation to follow the standards.
} 
process, especially the provision of cross border aviation, ${ }^{19}$ must be started in a global point of view to generate a global unity of civil aviation. ${ }^{20}$

The elements of ICAO regulation consist of several aspects. The first is Chicago Convention 1944 as the main source of law. The second is additional rule of Annexes that commonly consists of standards and recommended practices. ${ }^{21}$ The third is technical rule out of standards and recommendation in applying Annex provisions. The fourth is a procedure of Air Navigation Service Operation of Aircraft (PANS-OPS) that has similar provisions with Annex but cannot be put there due to some situations. ${ }^{22}$

The ICAO generates many international treaties to become the source of law of aviation in both private and public. International treaties of aviation, publicly, regulate the security of flight. They are, among others, the Tokyo Convention 1963: Convention on Offences and Certain Other Acts Committed on Board Aircraft; the Convention of Den Haag 1970: Convention for the Suppression of Unlawful Seizure of Aircraft; the Montreal Convention 1971: Convention for the Suppression of Unlawful Acts Against the Safety of Civil Aviation; the Protocol Montreal 1988: Protocol for the Suppression of Unlawful Acts of Violence at Airports Serving International Civil Aviation; and the Montreal Convention 1991: Convention on the Making of Plastic Explosive for the Purpose of Detection.

The Assembly 39th Session - ICAO put some treaties to be applied by member states. Indonesia has ratified some of them.

Table 1. Recent Development: Some Ratified Treaties

\begin{tabular}{|l|l|l|}
\hline No & \multicolumn{1}{|c|}{ Treaty } & \multicolumn{1}{c|}{ Summary } \\
\hline 1 & $\begin{array}{l}\text { Protocol Relating to an } \\
\text { Amendment to the Convention } \\
\text { on International Civil Aviation }\end{array}$ & $\begin{array}{l}\text { This treaty amendment had been ratified by 127 } \\
\text { states. Article 56 of the Convention of Chicago } \\
\text { describes the regulation about Air Navigation }\end{array}$ \\
\hline
\end{tabular}

19 The ICAO officiate to standardize, enforce international standard, recommend the technical terms of practice and procedure in aviation, personnel license, air regulation, airplane utilization, registration sign and its eligibility in nation, air worthiness, aeronautical telecommunication, air traffic institution, rescue team, airplane accident investigation, aerodromes, aeronautical information institution, air engine sound \& engineering, security and safe transportation over the harmful items.

20 Niels van Antwerpen, Cross Border Provision of Air Navigation Services with Specific Reference to Europe: Safeuarding Transparent of Responsibility and Liability, The Netherlands: Kluwer Law International BV, 2008, p. 23. See Article 43-96 Chicago Convention of 1944.

21 Standards are provisions to be obeyed for safety purpose. If a state cannot conduct one of the provisions exist on standards, they have to inform the ICAO. These standards mean any kinds of physical characters, configurations, materials, performances, personnel or procedures, and unity of application that are important in conducting air navigation regulation for all members. If one cannot fulfill, it has to notify the board as stated in Article 38. Recommended practice is provision to be applied by states for safety purpose. Recommended practice is any physical characteristic specification, configuration, material, performance, personnel and procedure, unity of application that are important to safety, regulation and effectiveness of international air navigation for all of the members. Set of standards and recommendation, later, are reconstructed for convenience purpose that is known as Appendixes.

22 T. Bambang Widiarto, Tinjauan Hukum Udara sebagai Pengantar: Dalam Perspektif Hukum Internasional dan Nasional, Jakarta: Pusat Studi Hukum Militer, 2015, pp. 25-26. 


\begin{tabular}{|c|c|c|}
\hline & (Article 56) & $\begin{array}{l}\text { Commission. It consists of commission members, } \\
\text { election of Air Navigation Commission President, } \\
\text { and its job descriptions. Prior to the amendment, } \\
\text { Article } 56 \text { says, there were } 15 \text { members of the Air } \\
\text { Navigation Commission. It turned to } 19 \text { after } \\
\text { amendment. Due to this Protocol, Indonesia has } \\
\text { ratified it in the Presidential Decree Number } 67 \\
\text { of } 1995 \text {. }\end{array}$ \\
\hline 2 & $\begin{array}{l}\text { Protocol Relating to an } \\
\text { Amendment to the Convention } \\
\text { on International Civil Aviation } \\
\text { (Article } 50 \text { (a)) }\end{array}$ & $\begin{array}{l}\text { Article } 50(a) \text { in the Convention of Chicago tells } \\
\text { the rule of council members. Prior to the } \\
\text { amendment, this article states that there were } \\
33 \text { council members. It becomes } 36 \text { after the } \\
\text { amendment. Indonesia has ratified it by } \\
\text { establishing the Presidential Decree Number } 66 \\
\text { of } 1995 \text {. This treaty had been ratified by } 142 \\
\text { states. }\end{array}$ \\
\hline 3 & $\begin{array}{l}\text { Convention for the Unification } \\
\text { of Certain Rules for } \\
\text { International Carriage by Air } \\
\text { (Montreal Convention 1999) }\end{array}$ & $\begin{array}{l}\text { The Montreal Convention } 1999 \text { was a } \\
\text { modification of the Warsaw Convention that was } \\
\text { more complex. The Montreal Convention } 1999 \\
\text { was valid since November } 4,2003 \text {. This Treaty } \\
\text { had been ratified by } 136 \text { states of ICAO. } \\
\text { Indonesia has ratified this convention in the } \\
\text { Presidential Regulation Number } 95 \text { of } 2016 \text {. } \\
\text { This Convention is valid for all international } \\
\text { carriage of passenger, baggage, or cargo } \\
\text { performed by aircraft. It is also valid to gratuitous } \\
\text { carriage by aircraft performed by an air } \\
\text { transport. according to this Convention, the } \\
\text { expression "international carriage" covers any } \\
\text { carriage situated either within the territories of } \\
\text { two States Parties, or within the territory of a } \\
\text { single State Party if there is an agreed stopping } \\
\text { place within the territory of another state, even if } \\
\text { the state is not a party. Carriage between two } \\
\text { points within the territory of a single state party } \\
\text { without an agreed stopping place within the } \\
\text { territory of another state is not international } \\
\text { carriage based on this Convention. }\end{array}$ \\
\hline 4 & $\begin{array}{l}\text { Convention on International } \\
\text { Interests in Mobile Equipment } \\
\text { (Cape Town Convention 2001) }\end{array}$ & $\begin{array}{l}\text { Indonesia has ratified the Cape Town Convention } \\
2001 \text { in the Presidential Regulation Number } 8 \text { of } \\
2007 \text {. The Cape Town Convention } 2001 \text { was } \\
\text { arranged due to the need for using and acquiring } \\
\text { high-value mobile equipment, which were } \\
\text { important to facilitate or authorize funding } \\
\text { efficiently. This Convention aims to set legal } \\
\text { instruments internationally in purchasing }\end{array}$ \\
\hline
\end{tabular}




\begin{tabular}{|c|c|c|}
\hline & & $\begin{array}{l}\text { airplane that is able to enhance international } \\
\text { aviation quality. Article } 2 \text { (1) of the Cape Town } \\
\text { Convention } 2001 \text { declares that the Convention is } \\
\text { intended to prepare the establishment and } \\
\text { enforcement of international interest toward } \\
\text { mobile equipment and associated rights in a } \\
\text { certain category. Article } 2 \text { (2) indicates the } \\
\text { international interest in mobile equipment. }\end{array}$ \\
\hline 5 & $\begin{array}{l}\text { Protocol to the Convention on } \\
\text { International Interests in } \\
\text { Mobile Equipment on Matters } \\
\text { Specific to Aircraft Equipment } \\
\text { (Cape Town Protocol 2001) }\end{array}$ & $\begin{array}{l}\text { This Convention had been ratified by } 76 \text { states. } \\
\text { Indonesia has ratified this protocol by } \\
\text { establishing the Presidential Regulation Number } \\
8 \text { of 2007. Based on Article III of the Protocol, the } \\
\text { convention provisions were valid if the } \\
\text { references of certain treaty were considered as } \\
\text { international interests. Article } 3 \text { refers to an } \\
\text { agreement creating or providing for international } \\
\text { interest. It is a reference to a contract of sale. } \\
\text { In addition, the general provisions of Article } 1 \text {, } \\
\text { Article } 5 \text {, Chapters IV to VII, Article } 29 \text { (other than } \\
\text { Article } 29(3) \text { which is replaced by Article XIV(1) } \\
\text { and (2)), Chapter X, Chapter XII (other than } \\
\text { Article } 43 \text { ), Chapter XIII and Chapter XIV (other } \\
\text { than Article 60) shall be applied to contracts of } \\
\text { sale and prospective sales. } \\
\text { Article } 3 \text { (1) states the Convention is valid for } \\
\text { helicopter, or to an airframe pertaining to an } \\
\text { aircraft, registered in an aircraft register of a } \\
\text { Contracting State which is the State of registry, } \\
\text { and where such registration is made pursuant to } \\
\text { an agreement for registration of the aircraft it is } \\
\text { deemed to have been effected at the time of the } \\
\text { agreement. }\end{array}$ \\
\hline 6 & $\begin{array}{l}\text { Protocol Relating to an } \\
\text { Amendment to the Convention } \\
\text { on International Civil Aviation } \\
\text { (Article 83Bis) }\end{array}$ & $\begin{array}{l}\text { This Protocol had been ratified by } 174 \text { states. It } \\
\text { regulated the shifting of certain function and } \\
\text { duty from registrants to operators. When an } \\
\text { airplane was already registered, operated by rent } \\
\text { agreement, switching airplane or any kinds of } \\
\text { similar regulations, registrant state was able to } \\
\text { switch the whole or a half functions and } \\
\text { responsibilities as it was based on Article 12, 30, } \\
31 \text { and } 32 \text { (a) of the Chicago Convention. } \\
\text { State would free from responsibilities since the } \\
\text { time of switched functions. This shifting would } \\
\text { not be valid before the treaty was registered to } \\
\text { the ICAO councils and released to public in } \\
\text { accordance to Article } 83 \text { of the Chicago }\end{array}$ \\
\hline
\end{tabular}




\begin{tabular}{|l|l|}
\hline & $\begin{array}{l}\text { Convention. This Treaty had been communicated } \\
\text { directly with states within the Treaty or the } \\
\text { states that had correlation with states under the } \\
\text { treaty deal. Due to this Protocol, Indonesia had } \\
\text { ratified it in the Presidential Decree Number } 21 \\
\text { of } 1987 .\end{array}$ \\
\hline
\end{tabular}

These are the lists of treaties, which are encouraged in Assembly $39^{\text {th }}$ Session ICAO that have not been ratified by Indonesia. They are as follows.

\section{a. International Air Service Transit Agreement (Transit Agreement 1944)}

Transit Agreement 1944 requires every state to give permission to other states based on freedom of the air for the scheduled international air services. States have the privilege to fly across other state's territory without landing for nonaviation purpose. Article 1 (paragraph 1) emphasizes the privileges with respect to airports utilized for military purposes to the exclusion of any scheduled international air services. ${ }^{23}$ This Treaty had been ratified by 133 states, except Indonesia. For Indonesia, which owns wide and strategic air territory, Transit Agreement 1944 provides influential impact on economic and security aspect. This interest is an important basis in the ratification of the agreement.

\section{b. Protocol Relating to an Amendment to the Convention on International Civil Aviation (Article 3 Bis) 1984}

The background of the amendment is the tragedy of shooting on Korean Airlines' Boeing 747. The principles of international law are added. It is known as the elementary considerations of humanity. Article 3 bis mentions that every state must refrain from resorting the use of weapons against civil aircraft in flight and that, in case of interception, the lives of persons on board and the safety of aircraft must not be endangered. This provision shall not be interpreted as modifying in any way the rights and obligations of States set forth in the Charter of the United Nations. Article 3 bis ensures that the regulation would not decrease the rights of the state party on self-defense. It also regulates the rights of state party regarding the procedures on handling civil airplane that trespass the air territory.

This Treaty had been ratified by 155 states, except Indonesia. For Indonesia, the ratification of the agreement should also consider rights on self-defense. Considering that the development of simultaneous aviation technology, the risk of threat through the air is higher. It opens up the possibility of utilizing civil airplane

23 Article 1 section 3 states "A contracting State granting to the airlines of another contracting State the privilege to stop for non-traffic purposes may require such airlines to offer reasonable commercial service at the points at which such stops are made. Such requirement shall not involve any discrimination between airlines operating on the same route, shall take into account the capacity of the aircraft, and shall be exercised in such a manner as not to prejudice the normal operations of the international air services concerned or the rights and obligations of a contracting State". 
to threaten national sovereignty and security as in $11 / 9 / 2001$. Furthermore, this article is also against the Government Regulation Number 4 of 2018 on Air Security. In Article 27 of the Regulation, weapon utilization is allowed for Indonesian National Army to enforce the law and sovereignty of the nation.

\section{c. Convention on Compensation on Damage Caused by Aircraft to Third Parties (General Risk Convention 2009)}

The General Risk Convention 2009 had been ratified by four states. This Treaty describes any interference actions that break the law considered as violation. This Convention is not applied for any damages caused by state airplane such as military, customs, and police plane. Based on this Convention, there is no compensation if the damage is not coming from a direct consequence from the accident or from the facts found during the flight over the air traffic area. The compensation covers damage caused by dead, physical, and mental injury. The damage caused by mental injury is compensated only when it comes from psychiatric conclusion following the accident leading to physical injury or death. The damaged property must also be compensated. For environmental damage, if it happens within the area that is regulated by state law, it has to be compensated as well. When the total amount of damage that has to be paid is over the regulation, Article 4 (1), there is a special way to solve that problem as long as the claims of dead, physical, and mental injury are fulfilled responsibly.

The rest of payment, in case existed, shall be fulfilled proportionally due to the other damages. Any conduct for compensation to any damage to the third party due to the aircraft that is flown against the operators, servants, or agents (yet it is established, whether based on this Convention or under a lawsuit or others) may only be proposed according to the requirement set by the Convention. It shall be performed without reducing the questions of who are the persons that has the right to fly and what are their respective rights.

The raison d'etre of the Convention is contained in its Preamble that the states parties to the Convention recognize the need to ensure adequate compensation for third parties who suffer damage resulting from events involving an aircraft in flight. The states parties also understand the need to modernize the Convention on Damage Caused by Foreign Aircraft to Third Parties on the Surface (signed in Rome on October 7, 1952) and the Protocol to Amend the Convention on Damage Caused by Foreign Aircraft to Third Parties on the Surface (signed in Montreal on September 23, 1978). ${ }^{24}$

24 Ruwantissa Abeyratne, "Liability for Third Damage Caused by Aircraft-Some Recent Developments and Issues", Springer Science Business Media, 2009, p. 92. 


\section{d. Convention on Compensation for Damage to Third Parties Resulting From Acts of Unlawful Interference Involving Aircraft (Unlawful Interference Compensation Convention 2009)}

This Treaty had been ratified by nine states. The approach is collective states' action for harmonization and codification of certain rules governing compensation for the consequences of an event of unlawful interference with aircraft in flight. A new Convention is expected to achieve an equitable balance of interests. This Convention covers damage to third parties which occurs in the territory of a State Party caused by an aircraft in flight on an international flight, as a result of an act of unlawful interference. Damage to a ship in or an aircraft above the high seas or the exclusive economic zone shall be regarded as damage occurring in the territory of the state in which it is registered. However, if the operator of the aircraft has its principal place of business in the territory of a state other than the state of registry, the damage to the aircraft shall be regarded as having occurred in the territory of the state in which it has its principal place of business.

Furthermore, damage to a drilling platform or other installation permanently fixed to the soil in the Exclusive Economic Zone or the Continental Shelf shall be regarded as having occurred in the territory of state party having jurisdiction over the platform or installation. It is based on international law, including the United Nations Convention on the Law of the Sea in Montego Bay on December 10, 1982. There shall be no right to compensation under this Convention if the damage is not a direct consequence of the event that gives rise thereto. Damages due to death, bodily injury, and mental injury shall be compensable. Damages due to mental injury shall be compensable only if caused by a recognizable psychiatric illness resulting either from bodily injury or from direct exposure to the likelihood of imminent death or bodily injury.

Where two or more aircraft have been involved in an event causing damage to which this Convention applies, the operators of those aircraft are jointly and severally liable for any damage suffered by a third party. If required by the law of the State where the damage occurred, the operator shall make advance payments immediately to natural persons who may be entitled to claim compensation under this Convention, in order to meet their immediate economic needs. Such advance payments shall not constitute as recognition of liability and may be offset against any amount subsequently payable as damages by the operator.

Indonesia has not yet ratified General risk convention 2009 and unlawful interference compensation convention 2009. Both agreement leads to complex legal and political impact relating to terrorist actions, the responsibility of States, and the balancing between compensating innocent third party surface victims and protecting innocent airline victims and other industry stake holders against acts of terrorism. 


\section{e. Convention on the Suppression of Unlawful Acts Relating to International Civil Aviation (Beijing Convention 2010)}

This Treaty had been ratified by 26 states, except Indonesia. The presence of fundamental change that is enacted in the Beijing Convention is the expanding of the old regulation by adding new unlawful acts on aviation such as: (1) the use of aircraft as a weapon, (2) the use of aircraft to release or discharge the $\mathrm{BCN}$ materials, and (3) The use of BCN to attack civil aircraft. The evolution, in this convention, is trying to spread the attacking acts definition to civil aircraft and internationalize the jurisdiction of the crimes which a state, slowly but sure, gives its rights on jurisdiction to international jurisdiction. ${ }^{25}$ In a case where crimes attacking civil aircraft are happened, state has no exclusivity. The implementation of exclusivity of state by a state in giving protection to the offender, in the end, cam be interpreted internationally as part of terrorism action by state. ${ }^{26}$

The following are the unlawful acts according to Beijing convention 2010. It is when any person unlawfully and intentionally

(1) performs an act of violence against a person on board an aircraft in flight if that act is likely to endanger the safety of that aircraft; or

(2) destroys an aircraft in service or causes damage to such an aircraft which renders it incapable of flight or which is likely to endanger its safety in flight; or

(3) places or causes to be placed on an aircraft in service, by any means whatsoever, a device or substance which is likely to destroy that aircraft, or to cause damage to it which renders it incapable of flight, or to cause damage to it which is likely to endanger its safety in flight; or

(4) destroys or damages air navigation facilities or interferes with their operation, if any such act is likely to endanger the safety of aircraft in flight; or

(5) communicates information which that person knows to be false, thereby endangering the safety of an aircraft in flight; or

(6) uses an aircraft in service for the purpose of causing death, serious bodily injury, or severe damage to property or the environment; or

(7) releases or discharges from an aircraft in service any $\mathrm{BCN}$ weapon or explosive, radioactive, or similar substances in a manner that causes or is likely to cause death, serious bodily injury or severe damage to property or the environment; or uses against or on board an aircraft in service any BCN weapon or explosive, radioactive, or similar substances in a manner that causes or is likely to cause death, serious bodily injury or severe damage to property or the environment.

25 Adhi Riadhy Arafah, "Evolution of Terrorism Act against Civil Aircraft", Indonesian Journal of International Law, Vol. 11, No. 22, 2011, pp. 188-189. See also Adi Kusumaningrum, Hukum Udara: Kepentingan Indonesia Indonesia di Ruang Udara Nasional, Malang: UB Press, 2019, p. 78.

26 Ibid. 


\section{f. Protocol Supplementary to the Convention for the Suppression of Unlawful Seizure of Aircraft (Beijing Protocol 2010)}

This Treaty had been ratified by 28 states except for Indonesia. Beijing Protocol significantly expands the scope of hijacking to include the hijacking that happens before or after the flight, as well as various types of additional unlawful acts.

Meanwhile, the Hague Convention limits the violation to individuals on board, Beijing Protocol omits such requirement, and admit that not all individuals involved in plane hijacking are physically on board. The Protocol then covers the requirement for extradition and legal assistance more specifically than the Hague Convention that underlies, specifically, establishing that the demand for extradition or legal assistance may not be refused with the sole reason that it was a political violation or violation inspired by a political motive. The violations based on the Beijing Protocol to whoever is ineligible and intentionally take or operate the aircraft control during in flight by force or threat, or any kind of intimidation or using other technologies.

Under the Beijing Protocol, making a threat to commit violation mentioned above or causing one being threatened, in a situation that indicates that such a threat is believable is also classified as a violation against the Protocol. In addition, according to the Protocol, one is considered committing violation based on condition if one rules, directs other people, or setting a threat for the flight, or one participates as the accomplice in the violating commission that is set by Protocol. Furthermore, Protocol covers the safety clause that allows any denial of aid if the requested state has a strong base in ensuring that the request is made to prosecute individuals for the race, religion, nationality, ethnicity, political view or the gender. In term of jurisdiction, the responsibility is imposed to the state that becomes the Protocol Party in taking action needed to establish the jurisdiction upon the violation made based on the Protocol and the other violation towards the passengers or crews that is done by the suspect due to the violation. However, for a state to make such jurisdiction, the violation must be done in the state, or on board of pane registered in the state, or on board of plane that lands in the state with the presumption that the suspect is still on board.

Above all, every state that becomes the members of Beijing Protocol 2010 is mandated to establish the jurisdiction when the individual that is suspected of committing the violation present in the area and does not extradite the suspect. The Protocol also covers the safety clause that permits the denial of aid if the state requested has a strong base in believing that the request is made to prosecute individuals for the race, religion, nationality, ethnicity, political view, or the gender.

\section{g. Protocol to Amend the Convention on Offences and Certain Other Acts Committed on Board Aircraft (Montreal Protocol 2014)}

Unruly Passenger is possible to happen in flight. Unruly and disruptive behaviour committed by a small minority of passengers has become a significant issue facing 
airlines and their crew around the world. Such behaviour includes physical assault of other passengers or cabin crew, harassment, refusal to comply with safety instructions, making threats that could jeopardize the safety of the flight, and other acts that impact good order and discipline onboard. IATA has been collecting global data on unruly and disruptive passenger incidents since 2007. In 2017, there was one incident for every 1,053 flights (2016: one incident for every 1,424 flights).The proportion of very serious Level 3 (life threatening) and Level 4 (attempted breach of the flight deck door) incidents increased sharply in 2017, which is a matter of concern. $^{27}$

Montreal Protocol 2014 is made to alter and to add the jurisdiction of state of landing and the distinction between state of registration and state of the operator. It is a new development in the aviation business, admits the status and gives the immunity upon IFSO, and gives the right to anyone that demands refund for any loss caused by the unruly Passenger. This study is in the position that Indonesia needs to ratify Montreal Protocol 2009 considering the high rate of unruly passenger cases in Indonesia. This convention significantly improves the ability for states to prosecute unruly and disruptive passengers for acts or offences committed onboard flights that land in their territory, even in cases where the aircraft is registered in another state.

\section{The International Treaties Relating to Economic Activity}

In economic aspect, the legal order still developed in different levels, such as domestic, regional, up to global level. ${ }^{28}$ The example of national legal order is the international policy developed by the government of Canada called "Blue Sky" in 2006. This policy concerns with the negotiation of air services, and developed gradual changes in the form of reduction and limitation of air service agreement into "open skies" agreement. ${ }^{29}$ Other initiatives made is the regulation on market access for foreign airlines in such states as follows: Bahrain, Cambodia, Chile, China, Ecuador, Guatemala, Honduras, India, Kuwait, Lebanon, Morocco, Pakistan, Philippines, Sri Lanka, Tunisia, the United Arab Emirates, Japan. And or the regulation on "fare" determination by airlines in the United Kingdom Civil Aviation Authority as well as the regulation on airlines appointed in Bangladesh, India, Kuwait and Nigeria. The national legal order is established to encourage the liberalization in the airfreight industry, ${ }^{30}$ as it is done in Brazil, China, India, Japan, Indonesia, Mozambique, Saudi Arabia, and Thailand.

27 International Civil Aviation Organization, Progress with Regard To Promotion Of The Protocol To Amend The Convention On Offences And Certain Other Acts Committed Onboard Aircraft (Montreal Protocol Of 2014), Woring Paper, A40-WP/335.LE/92/8/19, p. 2.

28 Francesco Gaspari, The EU Air Transport Liberalization and Re-Regulation, International and Comparative Law Review, Vol. 11, No. 2, 2011, p. 7.

29 Ibid.

30 Ibid. 
Article 1 and 6 of Chicago Convention 1944 is the "legal basis" for the exchange of freedom of air. ${ }^{31}$ According to Have, the freedom of the air and bilateral agreement is the heart of Chicago Convention $1944 .^{32}$ Zylicz also emphasizes it as follows. ${ }^{33}$

"Within the scheme of international air law, based on complete and exclusive sovereignty and its consequences recognized by customary law, and bearing in mind the limited scope of application of multilateral and regional agreements, states that desire to establish and regulate international flights and commercial air service between and beyond their territories, usually gravitate towards bilateral negotiations."

Bilateral regulation in aviation so far is made in the form of agreement, MoU or arrangements between two states. Different from national and multilateral regulation, bilateral regulation do have any permanent institution or organization. Kassim and Handley state that bilateral agreement has five main characteristics as follows.

1. Bilateral agreement identifies or 'appoint' the airlines that may operate or provide international services (a single airline designated)

2. Bilateral agreement determine the route allowed (service permitted to specified points only) and the limited "five freedom".

3. Bilateral agreement contains requirements regarding the frequency and capacity fairly and provide opportunity equally.

4. Government have the authority to control (start from creating the regulation, inspecting, and imposing fine) on determining fare.

5. Bilateral agreement also determines the "safeguard clause". ${ }^{34}$

The bilateral system is the best response to the traditional concept of "state sovereignty" and the restriction policy that is based on this treaty model. Bilateral Treaty between these two nations gives mutual rights and obligations, exclusively. The bilateral agreement is more useful, flexible, compromise, the balance of right, opportunity, advantage, and reconciliation as well. ${ }^{35}$

However, a bilateral agreement is considered weak in some points during the time of international air transport development. As an evidence, it is not quite

31 The Chicago Convention as the 'legal basis' of bilateralism is also explained by B. D.K. Henaku, Regionalism in International Air Transport Regulation, Leiden: Koma Publisher Faundation, 1993, p. 9.

32 Brian F. Havel, Beyond Open Skies, A New Regime for International Aviation, Netherland: Kluwer International Law, 2009, p. 103.

33 Marek Zylicz, International Air Transport Law, Dordecht: Martinus Nijhoff Publishers, 1992, p. 135.

34 Hussein Kassim and Handley Stevens, Air Transport and The Eropean Union: Europeanization and its Limit, United Kingdom: Palgrave Macmillan, 2010, p. 25.

35 Adi Kusumaningrum, Kedaulatan Negara di Ruang Udara dan Perkembangan Angkutan Udara Internasional, Malang: UB Press, 2018, p. 95. 
good economically. This system cannot harmonize, organize, and maximize the global aviation network. ${ }^{36}$ In addition, it makes the development of an international regime not possible to organize long-term global economic events with consistent legal principles. This system rules global trade scheme too much and hampers it. Other than that, this system is getting outdated because of the internal and external liberalization of air transport's growth.

Wassembergh differentiates bilateralism and multilateralism as "any international cooperation between more than two states". He continues to explain that multilateral cooperation can be worldwide or regional (regionalism). As stated by the ICAO Manual on the Regulation of International Air Transport, Montreal, at 2.3-1 (2004), 'multilateral regulation' is

"regulation undertaken jointly by three or more States, within the framework of an international organization and/or a multilateral treaty or agreement, or as a separate specific activity, and maybe broadly construed to include relevant regulatory processes and structures, outcomes or output written as treaties or other agreements, resolutions, decisions, directives or regulations, as well as the observations, conclusions, guidance and discussions of multinational bodies, both inter-governmental and nongovernmental".

It can be concluded that multilateral regulation can be made along with three or more states in international organization framework and/or multilateral Treaties such as ICAO, WTO (World Trade Organization), OECD (Organization for Economic Cooperation and Development) and UNCTAD (United Nation Conference on Trade and Development). ${ }^{37}$ Zylics argues that global air transport system cannot be reached without multilateral liberalization.

As time goes by, this multilateral treaty pledges aviation elements more freely that is well-known as 'open sky policy'. The characteristics $\operatorname{are}^{38}$ (1) multiple designations, (2) each airline can access all of the available points on the destination states with unlimited freedom right, (3) government cannot regulate the flight's frequency and capacity, (4) airlines may adjust their own rate (even the government rejects it), and (5) safeguard clause is ruled in multilateral system.

The scope of multilateral Treaty is not only global but also regional. Regionalism is one of the multilateral treaties that limited on some states in certain region. ${ }^{39}$ Many states have practiced regional cooperation in air force. Furthermore, the agreement is in the form of plurilateral treaty. The example is in the Multilateral

\footnotetext{
Marek Zylicz, op.cit, p. 143.

Francesco Gaspari, op.cit, p. 7.

38 Hussein Kassim and Handley Stevens, op.cit, p. 27.

39 Wassembergh, "The Future of Multilateral Air Transport Regulation in the Regional and Global Context", Annual of Air and Space Law, Vol. 8, 1983, p. 263.
} 
Agreement on the Liberalization of International Air transport (MALIAT) that is known as the 'KONA' open skies agreement. It was signed on 2001 by five member states of the Asia-Pacific Economic Cooperation (APEC): Brunei, Chile, New Zealand, Singapore, and USA. ${ }^{40}$

\section{Sovereignty and New Standardization of International Air Law}

The participation and or the self-association of a state to the treaties of international aviation, in de facto, it transforms the sovereignty of a state upon the airspace from still become "complete" and "exclusive" into limited, relative and dynamic. Based on juridical perspective, it still refers to the Article 1 and 6 of the Chicago Convention 1944. The trade of flight elements is still based on two main principles of international airspace law those are "sovereignty" and "special permission or other authorization".

The sovereignty of a state upon the airspace is limited by the international aviation treaties that eventually affect the capability of the government to control the utilization and the maintenance of airspace. The characteristics of limited here are pushed by the birth of new actors such as the international organization that receive an allocation of power from the state through the international treaties. The characteristics of a relative for the state sovereignty upon the airspace is signified with the influence of utilization and the maintenance especially for the aviation sector because the change of paradigm that happen to the aviation industry.

State sovereignty as "the basic constitutional doctrine of the law of nations" ${ }^{41}$ is highest power that is final and absolute, but is not unlimited. Kusumaatmadja mentions that the sovereignty is a characteristic or essential feature from the state, where the state is sovereign, but it has limits that are the scope of the state, outside the area of the state, it has no power anymore. ${ }^{42}$ Parthiana gave the limitation upon the state sovereignty through the law of national as well as international. ${ }^{43}$ Parthiana stated that the sovereignty can be interpreted as the highest power that is absolute, whole, complete and cannot be divided and that is why it can be placed under other sovereignty as well as that it cannot be interpreted that sovereignty has no limit. ${ }^{44}$ Parthiana stated that the sovereignty could be interpreted as the highest power that is absolute, whole, complete and cannot be divided and that is why it can be placed under other sovereignty as well

Ibid., p. 7.

41 Ian Brownlie, Principles of Public International Law, Ninth Edition, Oxford: Clarendon Press, 2008, p. 289.

42 Mochtar Kusumaatmadja, Pengantar Hukum Internasional, Bandung: Alumni, 2003, p. 18.

43 I Wayan Parthiana, op.cit, p. 294.

44 The sovereignty concept that is limited only to the state and only in the certain area limit is made right after a series of treaties of Peace of Westphalia on 1648 that ended the 30-years-war between the Roman Empire and the protestant states, as well as the erasing the universal power of Pope and Roman Empire. See Mattew S. Weinert, Democratic Sovereignty Authority, Legitimacy, and State in a Globalizing Age, New York: University College of London Press, 2007, p. 20. 
as that it cannot be interpreted that sovereignty has no limit. ${ }^{45}$ Grotius stated that the sovereignty is not absolute. The authority of a state and the governance is also limited; in most states, it is limited by the rules of law. ${ }^{46}$ Meanwhile, Nico Schrijver emphasizes that as a dynamic concept, indeed sovereignty is still frequently seen as same with "supremacy" and "absolute". Furthermore, Schrijver states that sovereignty has a lot of variety of definition that can be seen from the period of history as well as the main characteristics, which still exist. ${ }^{47}$

States recently willingly or not have pushed them to adjust their national law with the standardization of international law. The ICAO does one of the standardization of the air transport, such as in term of safety and security of flight. This standardization causes the transition from hierarchic state-centric world to the non-hierarchic multi-centric world. ${ }^{48}$ Therefore, the classical doctrine that based on the assumption that all states have the same sovereignty has become a question.

\section{Conclusion}

Internationalization standard is a way to respond to the special needs of globalization and the more complex new aviation order. Following the World War II, interaction and cooperation among states increase. This is in line with the development of science, technology, and international trade, including the flight service. As a result, the number of governmental and non-governmental organizations increases. It is followed by the extension of international law. Furthermore, international treaty or agreement has become sources of national (domestic) law for almost states of the world. Consequently, the addition of international rules to the national law of state happens. States are bound legally and politically upon the decree of international organization where they are members.

In the context of recent International law, the boundaries between international law and national law have become indistinct. Legal rule and decisionmaking process of international organization must be based entirely on democratic procedure for all member states. It has no excuse either in term of decision making for final text, the negotiation, and the drafting of a rule or resolution. In the context of national law, a state consent to be bound by international treaty should also consider national interest.

\footnotetext{
Nico Schrijver, op.cit, p. 71.

Ibid.

Ibid., p. 70.

48 In the ASEAN, Indonesia has contributed in, among others: ASEAN Cooperation on Aircraft Search and Rescue, ASEAN Multilateral Agreement on Commercial of Non-Scheduled Air Services, and The ASEAN Aviation Training and Education Summit. ASEAN Cooperation on Aircraft Search and Rescue. Furthermore, in economic area, Indonesia has ratified three agreements such as: ASEAN Multilateral Agreement on Air Services (AMAAS) with President Regulation No. 74 Year 2011, ASEAN Multilateral Agreement on the Full Liberalization of Air Freight Services (AMAFLAFS) with President Regulation No. 74 Year 2015, and ASEAN Multilateral Agreement on the Full Liberalization of Passenger Air Services (AMAFLPAS) with President Regulation No. 12 Year 2016. (Adi Kusumaningrum, 2019).
} 
National interests refer to not only legal aspects but also political and security aspects. Ratification of treaties on aviation should acknowledge implications of legal, political, and security aspects. In the case of Indonesia, a basic value that should not be forgotten is that Indonesia is located in a geographically and geopolitically strategic location providing great airspace benefits.

\section{References}

\section{Books}

Abeyratne, Ruwantissa, Essential Air and Space Law, Eleven International Publishing, Utrecht, 2008.

Adi Kusumaningrum, Kedaulatan Negara di Ruang Udara dan Perkembangan Angkutan Udara Internasional, UB Press, Malang, 2008.

Hukum Udara: Kepentingan Indonesia Indonesia di Ruang Udara Nasional, UB Press, Malang, 2019.

Brownlie, Ian, Principles of Public International Law, Ninth Edition, Clarendon Press, Oxford, 2008.

Cheng, Bin, The Law of International Air Transport, The London Institute of the World Affairs, London, 1962.

Demhsey, Paul Stephen, Air Law, Mc Gill University, Montreal, 2008.

Havel, Brian F., Beyond Open Skies, A New Regime for International Aviation, Kluwer International Law, Netherland, 2009.

Henaku, B. D. K., Regionalism in International Air Transport Regulation, Koma Publisher Faundation, Leiden, 1993.

I Wayan Parthiana, Pengantar Hukum Internasional, Mandar Maju, Bandung, 2002. , Perjanjian Internasional Bagian 1, CV. Mandar Maju, Bandung, 2002.

Kassim, Hussein and Handley Stevens, Air Transport and The European Union: Europeanization and its Limit, Palgrave Macmillan, United Kingdom, 2010.

Kasper, Daniel M., Deregulation and Globalization: Liberalizing International Trade in Service, Balinger Publishing Company, Massachusetts, 1998.

K. Martono and Usman Melayu, Perjanjian Angkutan Udara di Indonesia, Mandar Maj, Bandung, 1996.

Mochtar Kusumaatmadja and Etty R. Agoes, Pengantar Hukum Internasional, Alumni, Bandung, 2003.

Shinta Dewi, Peran Hukum Dalam Pembangunan di Indonesia: Kenyataan, Harapan dan Tantangan, Remaja Rosdakarya, Bandung 2003.

T. Bambang Widiarto, Tinjauan Hukum Udara sebagai Pengantar: Dalam Perspektif Hukum Internasional dan Nasional, Pusat Studi Hukum Militer, Jakarta, 2015.

Antwerpen, Niels van, Cross Border Provision of Air Navigation Services with Specific Reference to Europe: Safeguarding Transparent of Responsibility and Liability, Kluwer Law International BV, Netherland, 2008. 
Susi Dwi Harjanti, Negara Hukum yang Berkeadilan, Pusat Studi Kebijakan Negara Fakultas Hukum Universitas Padjadjaran (PSKN FH UNPAD), Bandung, 2011.

Wallace, M. Rebecca, Hukum Internasional, translated by Bambang Arumanadi, IKIP Semarang Press, Semarang, 1996.

Weinert, Mattew S., Democratic Sovereignty Authority, Legitimacy, and State in a Globalizing Age, University College of London Press, New York, 2007.

Zlicz, Marek, International Air Transport Law, Martinus Nijhoff Publishers, Dordecht, 1992.

\section{Other Documents}

Abxeyratne, Ruwantissa, "Liability for Third Damage Caused by Aircraft-Some Recent Developments and Issues", Springer Science Business Media, 2009.

Adhi Riadhy Arafah, "Evolution of Terrorism Act Against Civil Aircraft", Indonesian Journal of International Law, Vol. 11, No. 2, 2011.

Gaspari, Francesco, "The EU Air Transport Liberalization and Re-Regulating", International and Comparative Law Review, Vol.11, No. 2, 2011.

International Civil Aviation Organization, "Progress with Regard To Promotion Of The Protocol To Amend The Convention On Offences And Certain Other Acts Committed Onboard Aircraft" (Montreal Protocol Of 2014), Working Paper, A40-WP/335.LE/92/8/19.

Schrijver, Nico, "The Changing Nature of State Sovereignty", British Yearbook International Law, Vol. 70, Issue 1, 2000.

Wassembergh, "The Future of Multilateral Air Transport Regulation in the Regional and Global Context", Annual of Air and Space Law, Vol. 8, 1983.

\section{Legal Documents}

Convention on International Civil Aviation, 1944.

International Air Service Transit Agreement, 1944.

International Air Transport Agreement, 1944.

Convention on Offences and Certain Other Acts Committed on Board Aircraft, 1963.

Vienna Convention on the Law of Treaties, 1969.

The Vienna Convention on the Law of Treaties between States and International Organizations, 1986.

Convention for the Suppression of Unlawful Seizure of Aircraft, 1970

Convention for the Suppression of Unlawful Acts against the Safety of Civil Aviation, 1971.

Convention on the Marking of Plastic Explosives for the Purpose of Detection, 1991. Convention for the Unification of Certain Rules for International Carriage by Air, 1999.

Convention on International Interests in Mobile Equipment, 2001.

Convention on Compensation on Damage Caused by Aircraft to Third Parties, 2009. 
Convention on Compensation for Damage to Third Parties Resulting from Acts of Unlawful Interference Involving Aircraft, 2009.

Convention on the Suppression of Unlawful Acts Relating to International Civil Aviation, 2010.

Protocol Relating to an Amendment to the Convention on International Civil Aviation, 1977.

Protocol Relating to an Amendment to the Convention on International Civil Aviation, 1984.

Protocol for the Suppression of Unlawful Acts of Violence at Airports Serving International Civil Aviation, supplementary to the Convention for the Suppression of Unlawful Acts against the Safety of Civil Aviation, 1988.

Protocol to the Convention on International Interests in Mobile Equipment on Matters Specific to Aircraft Equipment, 2001.

Protocol Supplementary to the Convention for the Suppression of Unlawful Seizure of Aircraft, 2010.

Protocol to Amend the Convention on Offences and Certain Other Acts Committed on Board Aircraft 2014. 